\title{
Udział Krystyny i Czesława Bednarczyków w pracach redakcyjnych „Kultury” i „Orła Białego" (na przełomie lat czterdziestych i pięćdziesiątych XX w.)
}

Zanim jeszcze pierwszy tom poezji opatrzony sygnetem wydawniczym Oficyny Poetów i Malarzy wyszedł 20 kwietnia 1950 r. spod prasy Drukarni Polskiej M. Caplin and Co. Press ${ }^{1}$, Krystyna i Czesław Bednarczykowie zdążyli już zaznaczyć swoją obecność w środowisku literacko-artystycznym powojennej emigracji. Zgromadzili też wokół siebie grupę pisarzy i plastyków, których nazwiska pojawiać się będą przez najbliższe dziesięciolecia na kartach tytułowych publikowanych przez instytucję książek i łamach jej kwartalnika „Oficyna Poetów”.

W kręgu twórców Oficyny Poetów i Malarzy znaleźli się przede wszystkim poeci oraz artyści wywodzący się z szeregów żołnierskich II Korpusu, do których należał również C. Bednarczyk². Po uwolnieniu z sowieckiego łagru przemierzył on szlak bojowy armii gen. Andersa i dotarł do Włoch, gdzie walczył pod Monte Cassino i Bolonią. We Włoszech poznał swoją przyszłą żonę, która pracowała wówczas w wojskowych służbach pomocniczych. Tam też redagował i wydawał gazetę 14 Wileńskiego Batalionu Strzelców „Żbików" 5 Kresowej Dywizji Piechoty. Okres włoski był dla Bednarczyków ważny z jeszcze jednego powodu. Stali się oni wówczas częścią środowiska literackiego i artystycznego, do którego należeli również m.in. Józef Czapski, Kazimierz Sowiński, Gustaw Herling-Grudziński, Jan Bielatowicz, Tadeusz

\footnotetext{
1 Była to publikacja: J. Olechowski, Chwila nocna, okładka i rys. Z. Turkiewicza, Londyn 1950. Oficyna Poetów i Malarzy to polska emigracyjna instytucja łącząca wydawnictwo, drukarnię (pod nazwą The Poets' and Painters' Press) i redakcję kwartalnika artystyczno-literackiego „Oficyna Poetów". Działała w latach 1949-2011 głównie w Londynie, a jej plon wydawniczy i drukarski obejmuje ponad 700 tytułów. K. Bednarczykowa przekazała Uniwersytetowi Jagiellońskiemu spuściznę archiwalną założonej wraz z mężem Oficyny. Archiwum zostało przewiezione na Wydział Polonistyki UJ w 2012 r. Rok później otwarto Pracownię-Archiwum Oficyny Poetów i Malarzy, zajmującą się opracowywaniem zbiorów i udostępnianiem im studentom oraz badaczom.

2 O poezji C. Bednarczyka z czasów żołnierskich szerzej pisze J. Chłap-Nowakowa w książce Sybir, Bliski Wschód, Monte Cassino. Środowisko poetyckie 2. Korpusu i jego twórczość (Kraków 2004).
} 
Sułkowski, Bronisław Przyłuski, Józefa Radzymińska, Beata Obertyńska, Stanisław Gliwa i Zygmunt Turkiewicz. Po ewakuacji armii z Włoch, opuszczeniu Polskiego Korpusu Przysposobienia i Rozmieszczenia oraz przenosinach do Londynu Bednarczykowie założyli w 1949 r. Oficynę Poetów i Malarzy. W 1950 r. zamieszkali oni w Domu Pisarza przy Finchley Road, a rok później przeprowadzili się do polskiego szpitala psychiatrycznego w Mabledon Park (Tonbridge) ${ }^{3}$, gdzie podjęli współpracę z bardziej doświadczonym artystą drukarzem Stanisławem Gliwą. W 1952 r. Bednarczykowie przyjęli zlecenie od Petera Russella - angielskiego wydawcy Ezry Pounda - i przenieśli swoją skromną pracownię do pobliskiego miasteczka Tunbridge Wells. Nawiązanie znajomości z Feliksem Topolskim przy okazji prac nad Stacja Abbesses Stefanii Zahorskiej (1952) zaowocowało nie tylko wspólnym wydawaniem okazałej Topolski’s Chronicle, lecz także znalezieniem nowej, ostatniej już siedziby wydawnictwa oraz drukarni. Z pomocą F. Topolskiego - i w sąsiedztwie warsztatu artysty - Bednarczykowie wynajęli pomieszczenie pod przęsłem mostu kolejowego Hungerford Bridge w Londynie. Zajmowali je przez niemal czterdzieści lat, do 1991 r., kiedy z powodu podwyżki czynszu zmuszeni zostali do zamknięcia podmostowej drukarni. Wydawnictwo przenieśli wówczas do swojego domu, na Colindeep Lane w północno-zachodnim Londynie, gdzie istniało ono aż do śmierci K. Bednarczykowej w $2011 \mathrm{r}$.

Przy omówieniu pierwszego etapu działalności K. i C. Bednarczyków należy przede wszystkim zwrócić uwagę na inicjatywę powołania spółdzielni poetów i artystów, której historia sięga 1949 r. Ślady kształtowania się pomysłu zachowały się zwłaszcza w korespondencji Bednarczyków z zaufanymi współpracownikami (m.in. z Wacławem Iwaniukiem) oraz z tymi osobami, których pomysł zawiązania samopomocowej spółki żywo zainteresował (m.in. z Zygmuntem M. Jabłońskim, Jerzym Dołęgą-Kowalewskim, Michałem Chmielowcem). W liście do W. Iwaniuka z 1950 r. C. Bednarczyk objaśnił swoje zamiary względem zrzeszonych w spółdzielni twórców i ich dzieł:

pragnę zostawić zupełną swobodę autorom i malarzom przy budowie tomiku. Niech robią nowocześnie, wzbogacają pomysłowością, dbając o wygodę czytelnika i piękno książki. Pragnę z całego serca, by każdy z zainteresowanych poetów brał żywy udział w pracach Oficyny, by nadsyłał swoje uwagi i rady, bo dopiero wtedy może naprawdę powstać coś pięknego i doskonałego ${ }^{4}$.

3 Lecznicą kierował wówczas dr Jerzy Bram. Szpital mieścił siedzibę drukarni założonej niegdyś przez Anatola Krakowieckiego. Stanisław Gliwa przyjął tam posadę instruktora drukarstwa, a ponadto prowadził terapię zajęciową dla pacjentów. Na temat szpitala zob. M.E. Cybulska, Urywki kroniki szpitalnej. Mabledon Park Hospital, Londyn 1992.

4 Archiwum Emigracji w Toruniu, sygn. AE/WI/II, List C. Bednarczyka do W. Iwaniuka z 18 października 1950 r., k. nlb. 
Warto też podkreślić zarówno zabiegi K. i C. Bednarczyków zmierzające ku odnowie tradycji pięknej książki, jak i ich troskę o polską sztukę i dobrobyt artystów. Małżeństwo dołożyło bowiem starań, aby powiadomić społeczność emigracyjną o zamierzonym przedsięwzięciu wydawniczym oraz by wzbudzić jej zaufanie i uzyskać niezbędne wsparcie finansowe. Akcja informacyjna, tj. apele i prośby o zbiórkę funduszy, odbyła się we wczesnych latach pięćdziesiątych nie tylko na łamach prasy, lecz także w rozgłośniach radiowych. W niniejszym artykule chciałabym natomiast przyjrzeć się przede wszystkim współpracy debiutujących wydawców poezji z dwoma czołowymi periodykami emigracyjnymi, tj. „Kulturą” i „Orłem Białym”. Analiza spuścizn archiwalnych K. i C. Bednarczyków oraz Jerzego Giedroycia dowodzi bowiem, że w latach 1950-1951 założyciele Oficyny Poetów i Malarzy mieli dość poważny wpływ na dobór twórczości poetyckiej i artystycznej ukazującej się na łamach wspomnianego miesięcznika i tygodnika. Mowa tutaj wyłącznie o „Kulturze” i „Orle Białym”, ponieważ tylko w tych dwóch czasopismach ukazywał się autorski dział Oficyny Poetów i Malarzy. Wydaje się ponadto, że Bednarczykowie nie chcieli wówczas wikłać się w spory środowiska niezłomnych i „Kultury”, więc mimo różnic między poglądami redaktorów wskazywanych periodyków, spróbowali równocześnie porozumieć się z obydwoma naczelnymi.

Wśród najważniejszych opracowań dotyczących działalności Bednarczyków trzeba wskazać przede wszystkim zbiór wspomnień C. Bednarczyka $W$ podmostowej arkadzie. Wspomnienia drukarza $i$ wydawcy londyńskiej oficyny ${ }^{5}$ oraz rozprawę Marii Leskiej Londyńska Oficyna Poetów i Malarzy Czestawa i Krystyny Bednarczyków w latach 1949-19956. Ani monografist$\mathrm{ka}$, ani sam Bednarczyk nie omawiają jednak kwestii redagowania poetycko-artystycznych arkuszy na łamach „Kultury” i „Orła Białego” zbyt wnikliwie. Autorzy nielicznych poświęconych w całości lub częściowo Oficynie szkiców, tj. Andrzej Kłossowski ${ }^{7}$, Janina Zabielska ${ }^{8}$ oraz Ewa i Marek Pytaszowie $^{9}$, w ogóle nie poruszyli tego zagadnienia, zaś Mirosław A. Supruniuk ${ }^{10}$

\footnotetext{
Zob. C. Bednarczyk, W podmostowej arkadzie. Wspomnienia drukarza $i$ wydawcy londyńskiej oficyny, Londyn 1988. Drugie wydanie książki ukazało się w 2003 r.

6 Zob. M. Leska, Londyńska Oficyna Poetów i Malarzy Czesława i Krystyny Bednarczyków w latach 1949-1995, Londyn 1998.

7 Zob. A. Kłossowski, Polskie private i small presses na obczyźnie, [w:] Kultura skupisk polonijnych. Materiały z III sympozjum naukowego. Warszawa 12 i 13 maja 1988 r., Warszawa 1993. Zob. też tenże, Na obczyźnie. Ludzie polskiej ksiazżi, Wrocław 1984.

8 J. Zabielska, Instytucje i firmy wydawnicze - oficyny drukarskie, [w:] Literatura polska na obczyźnie 1940-1960, pod red. T. Terleckiego, t. 2, Londyn 1965, s. 570-571.

$9 \quad$ E., M. Pytaszowie, Bednarczykowie jako wydawcy (rekonesans), [w:] Pisarz na obczyźnie, pod red. T. Bujnickiego, W. Wyskiela, Wrocław 1985, „Biblioteka Polonijna”, t. 14.

10 M.A. Supruniuk, Para drukarzy godnych ballady, [w:] J. Kryszak, M.A. Supruniuk, Oficyna Poetów i Malarzy 1949-1991, Toruń 1992.
} 
wyłącznie napomknął o, ,ilustrowanych arkuszach poetyckich sygnowanych przez Oficynę Poetów i Malarzy"11, drukowanych w obu czasopismach. O wkładce K. i C. Bednarczyków dołączanej do wymienionych periodyków krótko napisała natomiast Regina Wasiak-Taylor w artykule Czestaw i Krystyna Bednarczykowie. Wydawcy, drukarze, poeci ${ }^{12}$. Warto więc uzupełnić tę lukę w badaniach nad dziejami Oficyny Poetów i Malarzy.

\section{Dział Oficyny Poetów i Malarzy w „Kulturze”}

Korespondencyjny, powojenny już dialog z J. Giedroyciem C. Bednarczyk nawiązał w czerwcu 1948 r., odpowiadając na skierowany do czytelników „Kultury” apel z prośbą o nadesłanie porad, komentarzy i zaleceń dotyczących sposobu redagowania miesięcznika. Przyszły wydawca z Oficyny Poetów i Malarzy podzielił się z redaktorem swoimi uwagami, z których jedna brzmiała następująco:

Otwórzcie Panowie szeroko drzwi dla młodych pisarzy i poetów, ale w drzwiach stańcie mocno z młotkiem i dłutem. Bądźcie surowymi po ojcowsku dla młodych i bierzcie w opiekę każdy młody talent. Dla znanych i uznanych bądźcie bezwzględnymi, jeśli zechcą drukować rzeczy słabe ${ }^{13}$.

Zasugerował ponadto prowadzenie działu kronikarskiego, w którym notowane byłyby wydarzenia kulturalne na świecie. Wskazówka ta nie była do końca uzasadniona, ponieważ Kronikę kulturalna umieszczono po raz pierwszy na łamach „Kultury” już w numerze marcowym z 1948 r. ${ }^{14}$

Wydaje się, że J. Giedroyc dostrzegł wówczas w C. Bednarczyku cennego i kompetentnego współpracownika, który mógł służyć radą zwłaszcza w ocenie emigracyjnej poezji ${ }^{15}$. Dowodzi tego m.in. prośba o opracowanie eseju poświęconego powojennej poezji polskiej w kraju ${ }^{16}$. Redaktor szukał kogoś, kto omówi zagadnienie „rzeczowo i obiektywnie” ${ }^{17}$. Ponadto z końcem stycznia

\footnotetext{
11 Tamże, s. 17.

12 Zob. R. Wasiak-Taylor, Czesław i Krystyna Bednarczykowie. Wydawcy, drukarze, poeci, „Zeszyty Naukowe PUNO” 2013, nr 1 (seria 3).

13 Archiwum Instytutu Literackiego (dalej AIL), sygn. KOR RED Bednarczyk, List C. Bednarczyka do J. Giedroycia z 7 czerwca 1948 r., k. nlb.

14 Zob. Z. Grocholski, Plastycy polscy w Paryżu, „Kultura” 1948, nr 5, s. 153.

15 Od 1954 r. doradztwem w kwestii poezji drukowanej i omawianej na łamach „Kultury” zajmował się Marian Pankowski, należący do grona najbliższych przyjaciół K. i C. Bednarczyków.

16 Zob. Pracownia-Archiwum Oficyny Poetów i Malarzy, Wydział Polonistyki Uniwersytetu Jagiellońskiego, (dalej PA OPiM), sygn. akc. 239a, List J. Giedroycia do C. Bednarczyka z 14 lipca 1950 r., k. 13.

17 Zob. jak wyżej. Ostatecznie pisaniem eseju zajął się Jan Olechowski. Pomimo ponagleń zwlekał on miesiącami z ukończeniem tekstu, wystawiając na próbę cierpliwość Bednarczyka i Giedroycia. Szkic nie ukazał się w „Kulturze”.
} 
1950 r. powierzył C. Bednarczykowi opiekę redakcyjną nad działem poetyckim (tj. działem „Oficyny Poetów i Malarzy”) w periodyku. Z listu Bednarczyka, w którym potwierdził on podjęcie się tego zadania, wynika również, że pomagał mu w nim będzie J. Olechowski ${ }^{18}$. Postawione przed C. Bednarczykiem wyzwanie wiązało się z obowiązkiem oceniania regularnie podsuwanej mu przez J. Giedroycia poezji. Po przeczytaniu wierszy recenzent odsyłał materiał wraz z opinią i korektą, którą z kolei przekazywano autorowi osądzonych utworów. Po miesiącu współpracy redaktor zaproponował jednak C. Bednarczykowi i J. Olechowskiemu inną formułę recenzencką:

Niech się Panowie zastanowią, czy nie warto dawać odpowiedzi redakcji w tej sprawie. Mimo ośmieszenia „poradnika poezji” prowadzonego w „Gazecie Polskiej” przez Kadena myślę, że przy dobrym prowadzeniu może to być pożyteczne ${ }^{19}$.

Do listu zwrotnego z 19 lutego 1950 r. C. Bednarczyk załączył próbne Odpowiedzi redakcji, które jednak - z niewiadomych przyczyn - nie zostały opublikowane w „Kulturze”20. Można się tylko domyślać, że nie przypadły do gustu redaktorowi, który pozostawiał sobie w decyzjach wydawniczych głos rozstrzygający, zwłaszcza jeśli szło o ocenę twórczości poetyckiej. Nie zgadzał się na przykład z opinią C. Bednarczyka o wierszach W. Iwaniuka, które nie zostały wyłonione wśród tekstów zaproponowanych do druku w dziale „Oficyny Poetów i Malarzy”. J. Giedroyc natomiast sądzil, że W. Iwaniuk jest ,poetą z prawdziwego zdarzenia”"21. Według londyńskiego wydawcy do najlepiej piszących zaliczali się wówczas Tadeusz Sułkowski,

18 Zob. AIL, sygn. KOR RED Bednarczyk, List C. Bednarczyka do J. Giedroycia z 20 stycznia $1950 \mathrm{r}$.

19 PA OPiM, sygn. akc. 239a, List J. Giedroycia do C. Bednarczyka z 14 lutego 1950 r., k. 2. Juliusz Kaden-Bandrowski (1885-1944) - prozaik i publicysta, w latach 1928-1939 kierownik działu literackiego „Gazety Polskiej”. Wcześniej, od 1923 do 1926 r., pełnił funkcję prezesa Związku Zawodowego Literatów Polskich w Warszawie.

20 J. Giedroyciowi spodobał się natomiast podpowiedziany przez londyńskiego wydawcę pomysł, aby w kręgach „Kultury” lub Oficyny powstał szkic o poezji z okresu obozów. Zob. AIL, sygn. KOR RED Bednarczyk, List C. Bednarczyka do J. Giedroycia z 19 lutego 1950 r.; PA OPiM, sygn. akc. 239a, List J. Giedroycia do C. Bednarczyka z 23 lutego 1950 r., k. 3.

21 PA OPiM, sygn. akc. 239a, List J. Giedroycia do C. Bednarczyka z 23 lutego 1950 r., k. 3. C. Bednarczyk musiał dość szybko zmienić zdanie o twórczości W. Iwaniuka, ponieważ już w sierpniu 1950 r. nie tylko poprosił poetę o przesłanie wierszy do oficynowego działu w „Orle Białym” i „Kulturze”, lecz także zaproponował pisarzowi wydanie tomiku. Zob. Archiwum Emigracji w Toruniu, sygn. AE/WI/II, list C. Bednarczyka do W. Iwaniuka z 13 sierpnia $1950 \mathrm{r}$. Innym pisarzem, którego twórczość nie wzbudziła podziwu londyńskiego wydawcy, był Ksawery Glinka. Osądził go surowo: „Koncert sentymentalny Xsawerego [!] Glinki - do kosza. Trzech groszy nie wart. Poeta ten spóźniony jest co najmniej o 50 lat. M.in. nie rozumie, że Picasso to wielki artysta. Poezji w nim prawie nie ma, a i jako wiersz nie zachwyca". AIL, sygn. KOR RED Bednarczyk, List C. Bednarczyka do J. Giedroycia z 16 lutego 1950 r. 
Bolesław Kobrzyński, Józef Łobodowski, Marian Pankowski, Henryk Mirzwiński, Jerzy Pietrkiewicz, Marian Czuchnowski, Bogumił Andrzejewski oraz J. Olechowski22. Poza tym na przełomie października i listopada $1950 \mathrm{r}$. wytworzyło się między J. Giedroyciem i C. Bednarczykiem pewne napięcie. Redaktor odrzucił bowiem jego recenzję dotyczącą Chwili nocnej J. Olechowskiego. Bez ogródek przyznał, że tekst mu się nie podoba ze względu na archaizowany język i zbytnią ogólnikowość. Decyzja ta nie miała jednak większego wpływu na ich dalsze stosunki.

Dla twórczości poetyckiej Giedroyc zarezerwował poczesne miejsce w wydawanym przez siebie miesięczniku już w jego pierwszej, rzymskiej edycji z czerwca 1947 r. Przekłady poezji Federica Garcii Lorki ogłosił wówczas J. Łobodowski ${ }^{23}$, w drugim numerze zaś pojawiły się wiersze Salvatore Quasimodo w tłumaczeniu B. Kobrzyńskiego. Na łamach późniejszych zeszytów gościli Kazimierz Wierzyński, W. Iwaniuk, B. Przyłuski, J. Radzymińska, J. Olechowski. W 1948 r. periodyk zyskał dział literacki, zatytułowany Arkusze poetyckie. W jego pierwszej odsłonie ukazały się utwory J. Pietrkiewicza, Thomasa S. Eliota i J. Łobodowskiego, natomiast w następnych - m.in. T. Sułkowskiego, J. Radzymińskiej, F. Garcii Lorki, M. Czuchnowskiego, Jewhena Małaniuka, H. Mirzwińskiego oraz Józefa Żywiny.

W podwójnym numerze „Kultury”, który ukazał się w lutym 1950 r., na stronie redakcyjnej widniał następujący komunikat: „Od następnego numeru wprowadzamy w «Kulturze» nowy dział pt. «Oficyna poetów i malarzy», redagowany przez członków «Grupy 49»"24. Nie wiadomo, czy

22 Zob. AIL, sygn. KOR RED Bednarczyk, List C. Bednarczyka do J. Giedroycia z 21 marca $1950 \mathrm{r}$.

23 J. Łobodowski był autorem publikowanego w „Kulturze” cyklu obejmującego wybory (najczęściej we własnym przekładzie) z antologii poezji różnych narodów, np. Antologia poezji białoruskiej, Mistycy hiszpańscy, Antologia poezji murzyńskiej.

24 „Kultura” 1950, nr 2-3 (28-29), s. 2. „Grupa 49” - awangardowa grupa artystyczna powołana w marcu 1949 r. w Londynie. Zaliczali się do niej inicjator, opiekun i mistrz zespołu Marian SzyszkoBohusz, a ponadto byli żołnierze II Korpusu, m.in. Zbigniew Adamowicz, Tadeusz Beutlich, Andrzej Bobrowski, Ryszard Demel, Antoni Dobrowolski, Kazimierz Dźwig, Janusz Eichler, Tadeusz ZniczMuszyński, Henryk Paar, Leon Piesowocki oraz Aleksander Werner. Większość z nich studiowała od 1945 r. pod okiem M. Szyszko-Bohusza w Szkole Malarstwa przy II Korpusie w Cecchignoli k. Rzymu, następnie w Polskim Studium Malarstwa i Grafiki Użytkowej (obozy PKPR Waldingfield Camp k. Sudbury, potem Kingwood Common k. Reading) oraz w Sir John Cass Institute of Art, Architecture and Design w Londynie. Współpraca K. i C. Bednarczyków z tą formacją zakończyła się, gdy J. Olechowski wskazał do publikacji w „Kulturze” dzieła artysty nienależącego do „Grupy 49”. Szerzej o niej pisał Jan W. Sienkiewicz w dwóch książkach: Sztuka w poczekalni. Studia z dziejów plastyki polskiej na emigracji 1939-1989, Toruń 2012 oraz Artyści Andersa. Continuità e novità, Warszawa 2014 (tutaj zwł. rozdz. 11: Grupa 49 - w poszukiwaniu wspólnego mianownika). O związku K. i C. Bednarczyków z „Grupą 49” zob. też M.A. Supruniuk, ,"Trwałość i płynność”. Sztuka polska w Wielkiej Brytanii w XX wieku - wstęp do opisu, „Archiwum Emigracji. Studia - Szkice - Dokumenty” 2006, z. 1-2 (7-8), s. 127-159. 
K. i C. Bednarczykowie zostali przyjęci do grupy, nie byli przecież plastykami. Pozostawali raczej na jej obrzeżach, luźno z nią związani. Zamierzali natomiast tworzących to grono malarzy i grafików zaprosić do swojej spółdzielni poetycko-artystycznej. Publikacja działu została w pierwotnym zamyśle przewidziana właśnie na luty $1950 \mathrm{r}$, ale termin ten przesunięto na kwiecień. J. Giedroyc po pierwsze bowiem musiał wywiązać się z przyrzeczeń i wydrukować w Arkuszach poetyckich wiersze Marka Gordona oraz Janiny Węgrzyńskiej-Kościałkowskiej, a po drugie - nie otrzymał od C. Bednarczyka ani J. Olechowskiego żadnej notatki redakcyjnej, która pozwoliłaby czytelnikom na zaznajomienie się z inicjatywą. Dopiero zatem w kwietniu 1950 r. oddano do rąk czytelników pierwszy oficynowy arkusz z wierszami Bednarczyka ${ }^{25}$ (*** [ziewnęto okno...], Notatka z Londynu, Pijany dom) oraz dwoma całostronicowymi Aktami Zygmunta Turkiewi$\mathrm{cza}^{26}$. Układ graficzny działu, za który odpowiadali K. i C. Bednarczykowie i Z. Turkiewicz, zyskał przychylność redaktora. W tym samym numerze, na stronach poprzedzających dział „Oficyna Poetów i Malarzy”, wydrukowano okazałe, całostronicowe Szkice z New Yorku Józefa Czapskiego.

Swoją rolę redaktora działu i krytyka poetyckiego C. Bednarczyk starał się odgrywać jak najrzetelniej. W liście do J. Giedroycia z lutego 1950 r. pisał:

Pragnę z całego serca, by w „Kulturze” ukazywały się wiersze najwyższej jakości artystycznej; by poeta, który zostanie wydrukowany tam z dumą podnosił głowę do góry; by droga do „Kultury” była ciężka, mozolna, najeżona sprawiedliwą, lecz ostrą oceną. Będziemy to robić w miarę wiedzy, wyczucia i $\mathrm{sit}^{27}$.

Następna edycja arkusza miała ukazać się jednak dopiero za pół roku. Opóźnienie przesyłki materiału do numeru majowego zostało spowodowane błędną informacją o regularnym przebiegu prac nad miesięcznikiem, przekazaną C. Bednarczykowi przez J. Olechowskiego ${ }^{28}$. W liście z 26 kwietnia 1950 r.

25 Na łamach „Kultury” K. Bednarczykowa ogłosiła drukiem swoje wiersze w 1964 (nr 5 (199), s. 55-56) i 1965 r. (nr 9 (215), s. 71).

26 Zob. „Kultura” 1950, nr 4 (30), s. 82-86. Warto dodać, że każdy z publikujących w oficynowym dziale twórców otrzymywał od redakcji egzemplarze autorskie i, prawdopodobnie, honorarium. Arkusz wywołał pozytywne reakcje czytelników. Pisał o tym Bednarczyk do Giedroycia w liście z 23 kwietnia 1950 r.: „Dział ten zrobił trochę szumu. Dostałem parę listów pochwalających naszą inicjatywę".

27 AIL, sygn. KOR RED Bednarczyk, List C. Bednarczyka do J. Giedroycia z 16 lutego 1950 r.

28 Olechowski mylnie sądził, że zespół „Kultury” zamyka numer każdego piątego dnia miesiąca, a następnie kieruje materiał redakcyjny do drukarni. Edycję majową powinien był zatem Bednarczyk przesłać przed 15 kwietnia. 
J. Giedroyc wyraźnie podkreślił, jak ważna dla niego jest punktualność, od której zależy comiesięczne wydawnicze powodzenie:

List Pana i doskonałe rysunki Kościałkowskiego przyjąłem ze zgrzytem zębów. Jak już Panu pisałem, przyszły formalnie 9 dni, a faktycznie o 5 dni za późno. W tut[ejszych] warunkach drukarskich muszę łamać numer w bardzo sztywnych terminach, bo cała procedura trwa b. długo. Jak już Panu pisałem, nie chcąc angażować Pana, dałem Arkusze poetyckie, na które złożyły się wiersze Łobodowskiego oraz Radzymińskiej. Materiał przez Pana nadesłany pójdzie w numerze czerwcowym, to znaczy rysunki Kościałkowskiego oraz wiersze Czuchnowskiego ${ }^{29}$.

Zeszyt czerwcowy miesięcznika nie zawierał jednak działu „Oficyny Poetów i Malarzy". Termin publikacji uległ zmianie z powodu niedopasowanych do formatu kolumny „Kultury” rysunków Mariana Kościałkowskiego, które - po przeniesieniu na drukarskie klisze z zachowaniem odpowiednich proporcji - uległyby znacznemu pomniejszeniu, a wtedy strona pozostałaby niemal pusta. J. Giedroyc poprosił wobec tego o inne, lepiej dobrane pod tym względem grafiki, a w czerwcu wydrukował utwory M. Czuchnowskiego i J. Radzymińskiej. Do podwójnego numeru wakacyjnego C. Bednarczyk wybrał nowe rysunki M. Kościałkowskiego oraz utwory Janusza Kucharskiego, Mariana Łysakowskiego, M. Czuchnowskiego i swoje własne. Tymczasem Arkusz poetycki w numerze lipcowo-sierpniowym wypełniły wiersze poetów ukraińskich w przekładzie J. Łobodowskiego, z kolei we wrześniu - utwory J. Pietrkiewicza i B. Andrzejewskiego. Tym razem winę za zwłokę w publikacji działu wzięli na siebie zarówno J. Giedroyc, który przyznał się do tego, że nie potrafił dotrzymać obiecanego terminu, jak i C. Bednarczyk, którego w połowie 1950 r. całkowicie pochłonęła organizacja i promocja wydawnictwa ${ }^{30}$.

K. i C. Bednarczykom przyszło zatem czekać aż do października. W oficynowym dziale o charakterze wyłącznie poetyckim (bo jednak bez rysunków M. Kościałkowskiego) umieszczono wiersze M. Czuchnowskiego (Pejzaż, Za każdą tzę), J. Żywiny (Akt, Śpiew na przednówku), M. Łysakowskiego (Pożegnanie z Francja), J. Kucharskiego (Nic więcej) oraz C. Bednarczyka (Metafory z Hyde Parku z dedykacją dla Z. Turkiewicza) ${ }^{31}$. Po październikowej edycji nastąpiła jednak przerwa, której przyczyną była

29 PA OPiM, sygn. akc. 239a, List J. Giedroycia do C. Bednarczyka z 26 kwietnia 1950 r.

30 W liście do J. Giedroycia z 13 sierpnia 1950 r. C. Bednarczyk pisał: „Ostatnio jestem bardzo zajęty. Korespondencja, «propaganda» Oficyny i wysyłka książek. Najsłabiej, jak dotąd, idą w Anglii. Stany, Kanada, Belgia - zadowalająco. Rozkręcamy się powolutku” (AIL, sygn. KOR RED Bednarczyk).

${ }^{31}$ Zob. „Kultura” 1950, nr 10 (36), s. 71-76. 
publikacja w Arkuszach poetyckich obszernego poematu W. Iwaniuka Dziennik z podróży tropikalnej $i$ wiersze o wojnie. J Giedroyc uprzedził C. Bednarczyka o konieczności wydrukowania tego utworu. W liście z 1 października 1950 r. tłumaczył:

Najgorsze, że znów w numerze listopadowym Panu nawalę, gdyż chcę dać jako arkusze poetyckie poemat Iwaniuka (który się Panu swego czasu nie podobał), a który muszę zamieścić z różnych względów. Natomiast grudzień obiecuję na pewno ${ }^{32}$.

„Względy”, o których wspomniał redaktor, mogły oznaczać nie tylko prawdziwe uznanie dla talentu poetyckiego W. Iwaniuka i zamiar zatrzymania go w kręgu bliskich współpracowników, lecz także chęć udzielenia twórcy wsparcia finansowego ${ }^{33}$.

Do ostatniego w 1950 r. zeszytu miesięcznika z Maisons-Laffitte redaktor przeznaczył wiersze C. Bednarczyka, J. Dołęgi-Kowalewskiego, H. Mirzwińskiego, M. Czuchnowskiego i B. Kobrzyńskiego. Niestety, w edycji grudniowej zamiast tych utworów pojawiła się Kantyczka duchowa św. Jana od Krzyża przełożona przez J. Łobodowskiego. Niektóre z wybranych do numeru grudniowego wierszy J. Giedroyc ogłosił wiosną $1951 \mathrm{r}$. w Arkuszach poetyckich ${ }^{34}$. W związku z tym w maju tego roku C. Bednarczyk pisał do redaktora w tonie pozbawionym pretensji: „Wydaje mi się, że mimo najlepszych chęci Pańskich i moich nie udało się nam regularnie zamieszczać Oficyny w «Kulturze»" ${ }^{35}$. W kolejnych numerach rubryka już się nie ukazała. Warto zauważyć, że C. Bednarczyk jako twórca działu poetyckiego „Kultury” nie mógł czuć się całkowicie swobodnie i w pełni samodzielnie decydować o doborze poezji. Choć redaktor nieraz zwracał się do londyńskiego wydawcy z prośbą o radę i krytykę wierszy, to jednak ostatnie słowo zawsze należało do J. Giedroycia. Większą niezależność zapewniało natomiast K. i C. Bednarczykom kierownictwo „Orła Białego”.

${ }_{32}$ Kopia listu J. Giedroycia do C. Bednarczyka z 1 października 1950 r. w: AIL, sygn. KOR RED Bednarczyk.

33 W liście do K.A. Jeleńskiego o wydaniu tomu wierszy W. Iwaniuka w 1959 r. pisał Giedroyc następująco: „Już i tak muszę zrobić szaleństwo i wydać tomik Iwaniukowi. Nie tylko dlatego, że jest zupełnie niezły, ale czuję, że jeśli tego nie zrobię, to Iwaniuk może się załamać psychicznie [...]. Jak Pan wie, nie idzie mi o filantropię, ale o utrzymanie tych kilku talentów autentycznych" (J. Giedroyc, K.A. Jeleński, Listy 1950-1987, wybrał, oprac. i wstępem opatrzył W. Karpiński, Warszawa 1995).

34 Zob. „Kultura” 1951, nr 4 (42), s. 54-58. W Arkuszach poetyckich z tego numeru zamieszczono następujące wiersze: Pola minowe M. Czuchnowskiego, Tintern Abbey M. Kobrzyńskiego, Muszla H. Mirzwińskiego, Wieża z kości słoniowej Zdzisława Jareckiego oraz Ulica Piwna Mieczysława Lurczyńskiego.

${ }^{35}$ AIL, sygn. KOR RED Bednarczyk, List C. Bednarczyka do J. Giedroycia z 18 maja 1951 r. 
Współpraca z zespołem „Kultury” nie ograniczyła się jednak tylko do redagowania działu Oficyny Poetów i Malarzy. J. Giedroyc, już wcześniej dostrzegający konieczność udzielenia wsparcia środowisku twórczemu na emigracji, nie pozostał obojętny wobec pomysłu powołania nowej grupy poetyckiej i założenia domu wydawniczego. W numerze styczniowym „Kultury” z 1950 r. redakcja w pochlebnym tonie omówiła ,zbiorowy wysiłek społeczny” ${ }^{36}$ Bednarczyków i „Grupy 49”, opisując zwięźle zasady finansowania spółdzielni (fundusz wydawniczy, dochody z wieczorów autorskich i wystaw) oraz jej plany wydawnicze, tj. publikowanie co kwartał jednego tomu poezji w bibliofilskim nakładzie i z reprodukcjami dzieł członków Oficyny. W artykule była ponadto wzmianka o zamiarze, jakkolwiek dość mgliście zarysowanym, stworzenia periodyku ,poświęconego wyłącznie zagadnieniom estetyki zarówno od strony poezji, jak i nowoczesnego malarstwa" ${ }^{37}$. Założenie czasopisma poetycko-malarskiego zatytułowanego „Awangarda” proponował Bednarczykom już w kwietniu tegoż roku J. Pietrkiewicz, któremu jednak odmówili. Rok później sami wystąpili z inicjatywą wydawania periodyku „Metafory”, poświęconego sztuce współczesnej, o którym Bednarczyk pisał następująco: „Będzie to żywe słowo pisarzy i malarzy naszej grupy, posłane każdemu interesującemu się kulturą ojczystą Polakowi"38. W 1954 r. z kolei W. Iwaniuk omawiał z K. i C. Bednarczykami pomysł stworzenia pisma „Poezja i Proza”, które kładłoby nacisk na „oryginalną twórczość pisarzy polskich na emigracji, zwłaszcza tych, którzy starają się wnosić coś nowego (nie w sensie Gombrowiczowskim)"39. Autor Pieśni nad pieśniami ubolewał nad brakiem periodyku walczącego o wartości artystyczne pisarzy na emigracji. „Wiadomości” uważał za „statyczne”40, a o „Kulturze” sądził, że „pełno [w niej - J.W.] kacyków, kadzicieli i proroctw politycznych na krótką metę"41.

Odkąd J. Giedroyc dowiedział się o zawiązaniu spółki wydawniczej K. i C. Bednarczyków, nie ustawał w okazywaniu im zaciekawienia i serdeczności. W liście z marca 1950 r. redaktor zasugerował:

36 „Kultura” 1950, nr 1 (27), s. 147. W tekście padła również informacja o miejscu spotkań Oficyny Poetów i Malarzy oraz organizowanych przez nią wieczorów autorskich. Była to udostępniona przez Zofię Arciszewską nowo otwarta kawiarnia „SIM” (Café „SIM”, Klub Białego Orła, 2, Albert Gate). Jej właścicielka wpłaciła we wrześniu 1950 r. znaczącą wówczas sumę 30 funtów na Fundusz Wydawniczy „Oficyny Poetów i Malarzy”. Warto ponadto zaznaczyć, że Arciszewska prowadziła znaną kawiarnię o tej samej nazwie („Sztuka i Moda”) w międzywojennej Warszawie. Stanowiła ona wówczas salon literacko-muzyczny. Występowali w niej m.in. Witold Lutosławski i Andrzej Panufnik.

37 Tamże.

38 PA OPiM, sygn. 3054, Maszynopis artykułu C. Bednarczyka pt. Oficyna Poetów i Malarzy.

39 PA OPiM, sygn. akc. 328a, List W. Iwaniuka do C. Bednarczyka z 10 września 1954 r., k. 18.

40 Tamże.

41 Tamże. 
Bardzo mnie interesuje wydawnictwo Pana i czekam szczegółowej kalkulacji. Tak na oko wygląda, że we Francji ceny drukarskie są tańsze o 30\% od tych, które Pan podaje. Jeśli to się rozkręci, to można by w przyszłości spróbować druku we Francji i formalnie sprowadzać potem do Angliii ${ }^{42}$.

C. Bednarczyk potraktował tę radę całkiem serio i w liście zwrotnym oznajmił, że następną książkę naprawdę opłacałoby się wydrukować we Francji; dodawał: „Szkoda, żeśmy się wcześniej w tej sprawie nie porozumieli. Dobrze się zresztą składa: «Kultura»-gmach i przy niej Oficyna"43. J. Giedroyc miał przesłać wydawcy kalkulację z drukarni, z której usług sam korzystał. Ostatecznie jednak, z powodów, które nie zostały wyłożone w ich korespondencji, K. i C. Bednarczykowie nie zdecydowali się skorzystać z tej możliwości.

Po ukazaniu się wiosną pierwszej pozycji opatrzonej sygnetem Oficyny Poetów i Malarzy redaktor „Kultury” zaoferował swoją pomoc w sprzedaży i promocji tomu. Obiecał zainteresować nim polskie składnice w Paryżu, tj. Libellę oraz Księgarnię Polską Stanisława Lama. Notę ogłoszeniową o zbiorze J. Olechowskiego zobowiązał się przekazać paryskiej prasie, tj. „Syrenie"44 i „Placówce”45.

Z kolei w lipcu 1950 r. J. Giedroyc umożliwił K. i C. Bednarczykom publikację całostronicowego komunikatu o subskrypcji na tomy Oficyny Poetów i Malarzy i zbiórce pieniędzy na jej fundusz wydawniczy. Warto przytoczyć tu ten apel w pełnym brzmieniu, ponieważ ukazał się w podobnym czasie na łamach innych czasopism emigracyjnych i stanowił jeden z najważniejszych elementów akcji promocyjnej podjętej przez londyńskich edytorów.

Literatura polska w Kraju znajduje się pod dławiącym terrorem bolszewizmu. Ani poeta, ani prozaik nie mają żadnej możliwości twórczego wypowiedzenia się. Jedyna forma literacka dozwolona w Kraju - to laurka na cześć Rosji i Stalina.

Twórczość literacka na emigracji MUSI utrzymać ciągłość wielkich polskich tradycji kulturalnych. Nikt nam nie pomoże - jeśli sami nie zrozumiemy potrzeby życia kulturalnego i nie poprzemy wysiłków indywidualnych poetów, prozaików, malarzy, aktorów i muzyków polskich na emigracji.

Zwracamy się do wszystkich Polaków na obczyźnie z apelem o poparcie naszej inicjatywy, jaką jest stworzenie OFICYNY POETÓw I MALARZY.

42 PA OPiM, sygn. akc. 239a, List J. Giedroycia do C. Bednarczyka z 9 marca 1950 r., k. 4.

43 AIL, sygn. KOR RED Bednarczyk, List C. Bednarczyka do J. Giedroycia z 21 marca 1950 r.

44 Tygodnik „Syrena”, ukazujący się w Paryżu od 1947 r., w kwietniu 1959 r. został włączony do londyńskiego „Orła Białego”.

45 „Placówka” była dwutygodnikiem politycznym związanym z ruchem Narodowej Demokracji, wydawanym w Paryżu przez Jana Matyasika od połowy lat czterdziestych. Publikacja pisma została zawieszona w czerwcu $1950 \mathrm{r}$. z powodu trudności finansowych. 
Grono poetów i malarzy zawiązało w Londynie spółkę samopomocową celem publikowania swoich prac. Jest to „Oficyna” wydawnicza, w której autorzy i wydawcy osobiście zajmują się artystyczną koncepcją wykonania książki, harmonizując elementy poezji z malarstwem.

Wspólna składka stała się początkiem skromnego funduszu wydawniczego, który pozwolił na wydanie zbioru poezji Jana Olechowskiego pt. Chwila nocna $\mathrm{z}$ rysunkami artysty malarza Zygmunta Turkiewicza. W przygotowaniu obecnie znajdują się dwa tomy poezji: Czesława Bednarczyka pt. Ścieżka i Mariana Czuchnowskiego pt. Pola minowe oraz Album artystyczny Zygmunta Turkiewicza.

Mimo pesymistycznych nastrojów, jakie panują na emigracji w dziedzinie spraw kulturalnych, artyści „Oficyny”, którzy w większości zarabiają na chleb pracą robotnika, wierzą, że znajdzie się 315 Polaków (tyle liczy egzemplarzy każdorazowo nakład) z pośród tysięcy przebywających poza granicami Kraju, którzy zgłoszą się bądź na stałych prenumeratorów, bądź wpłacą pewną, najmniejszą nawet kwotę na fundusz wydawniczy. Niniejszym rozpisujemy subskrypcję na:

a) Stałych prenumeratorów,

b) Fundusz wydawniczy „Oficyny Poetów i Malarzy ${ }^{46}$.

Redakcja „Kultury” pośredniczyła między Oficyną Poetów i Malarzy a subskrybentami i nabywcami jej pierwszych tomików (służąc pomocą chociażby w przekazie wpłat za prenumeraty). Publikowała ponadto wspólne ogłoszenia wydawniczo-księgarskie Oficyny Poetów i Malarzy oraz Składnicy Książki Polskiej Libella. Anonse pojawiły się na łamach miesięcznika w październiku i listopadzie 1952 r. Reklama dotyczyła tomów B. Przyłuskiego (Akord), F. Garcii Lorki (Wiersze) oraz Tymona Terleckiego (Paryż) „w pięknym wydaniu bibliofilskim, na specjalnym papierze, tłoczonych na ręcznej prasie oraz numerowanych" 47 . Zapowiedź przygotowywanego przez K. i C. Bednarczyków wraz z Kazimierzem Sowińskim Vade-mecum Cypriana Kamila Norwida J. Giedroyc obiecał zamieścić w „Kulturze” bezpłatnie: „Bardzo będę się cieszył, jeśli to choć trochę pomoże w Pana doskonałej robocie" $"$.

46 „Kultura” 1950, nr 7-8 (33-34), s. 92. Tom C. Bednarczyka nie ukazał się z przyczyn od Oficyny niezależnych. Zawiodła drukarnia, której Bednarczykowie powierzyli druk książki. Ścieżka miała być zbiorem 25 wierszy z rysunkami Z. Turkiewicza, ozdobną, półsztywną okładką, artystyczną oprawą, wydanym na na papierze dobrej jakości. Nie doszło także do publikacji albumu Z. Turkiewicza.

47 „Kultura” 1952, nr 10 (60), s. 162; nr 11 (61), s. 63.

48 PA OPiM, sygn. akc. 239a, List J. Giedroycia do C. Bednarczyka z 29 września 1952 r., k. 19. 


\section{Oficyna Poetów i Malarzy w „Orle Białym”}

Niezbadanym dotychczas zagadnieniem związanym z działalnością wydawniczą K. i C. Bednarczyków była również współpraca z „Orłem Białym”. Redakcja żołnierskiego tygodnika już w 1942 r. otworzyła łamy periodyku dla poetów, prozaików, publicystów i malarzy. Mieli oni wkrótce wejść do kręgu literacko-artystycznego skupionego wokół K. i C. Bednarczyków. Wśród nich znaleźli się J. Olechowski, J. Żywina, Janusz Wedow, B. Kobrzyński, Tadeusz Wittlin, Jan Bielatowicz, T. Sułkowski, M. Pankowski, M. Czuchnowski, J. Radzymińska, Maria Czapska, W. Iwaniuk, Aleksander Janta, K. Wierzyński oraz K. Sowiński. Zasadniczy wpływ na podniesienie poziomu pisma miał J. Giedroyc, który - jako szef wydawnictw wojskowych Wydziału Propagandy i Oświaty Armii Polskiej na Wschodzie - dowodził od 1943 do 1944 r. wraz z Józefem Czapskim pracami redakcyjnym i administracyjnymi „Orła Białego”.

C. Bednarczyk zadebiutował na łamach pisma w 1943 r., ogłaszając w dziale „Z poezji żołnierskiej” swój wiersz zatytułowany Droga ${ }^{49}$. Poeta znalazł się również w gronie autorów wierszy zebranych przez J. Bielatowicza w tomie Azja i Afryka. Antologia poezji polskiej na Środkowym Wscho$d z i e^{50}$, który należał do serii „Biblioteka Orła Białego”, ukazującej się pod redakcją J. Giedroycia. Na żołnierskim szlaku wydał ponadto C. Bednarczyk dwa tomy poezji: Na postojach. Iran, Irak, Palestyna oraz $W$ walce ${ }^{51}$.

Za oprawę graficzną „Orła Białego” odpowiadał m.in. Z. Turkiewicz ${ }^{52}$, który zimą 1949 r. zaprojektował sygnet wydawniczy Oficyny Poetów i Malarzy, a w 1950 r. przygotował rysunki do tomu C. Bednarczyka Ścieżka oraz zbioru J. Olechowskiego Chwila nocna. Warto zwrócić uwagę zwłaszcza na prace artysty zdobiące pierwsze strony specjalnych wydań świątecznych periodyku (tak wielkanocnych, jak i bożonarodzeniowych). Drugim plastykiem, który poprzez publikację swoich dzieł w periodyku znacznie przyczynił się do wzrostu poziomu artystycznego pisma, był Marian Szyszko-Bohusz, jeden z artystów malarzy współpracujących z K. i C. Bednarczykami od początku ich wydawniczej działalności. Z kolei od 1949 r. w rubryce Z teki ,Grupy 49” drukowano reproduk-

\footnotetext{
49 Zob. C. Bednarczyk, Droga, „Orzeł Biały”, 15.08.1943, nr 32, s. 10.

50 Zob. Azja $i$ Afryka. Antologia poezji polskiej na Środkowym Wschodzie, oprac. J. Bielatowicz, Oddział Propagandy i Kultury Dowództwa Armii Polskiej na Wschodzie, Palestyna 1944. W tomie swoje utwory opublikowali autorzy goszczący na łamach „Orła Białego”, m.in. Jerzy Bazarewski, Zdzisław Broncel, Władysław Broniewski, Jadwiga Czechowiczówna, M. Czuchnowski, Marian Hemar, B. Kobrzyński, Artur Międzyrzecki, H. Mirzwiński, K. Nałęcz, Beata Obertyńska, J. Olechowski, J. Wedow, Maria Petry, T. Wittlin, J. Żywina. Zbiór zawierał trzy wiersze C. Bednarczyka: Pustynia iracka, Kair oraz Droga.

51 Zob. C. Bednarczyk, Na postojach. Iran, Irak, Palestyna, Tel Awiw 1943; tenże, W walce, Tel Awiw 1945.

52 Z. Turkiewicz kierował działem plastycznym Wydziału Propagandy i Oświaty Armii Polskiej na Wschodzie. Szefem Wydziału był od 1942 r. J. Czapski.
} 
cje dzieł członków tytułowego środowiska artystycznego, którym opiekował się M. Szyszko-Bohusz (tytuł rubryki plastycznej zmieniał się i brzmiał również Z teki polskich rysowników lub Z teki rysowników). Alicja Drwęska, autorka kroniki artystycznej i szkiców krytycznych o sztuce, poświęciła „Grupie 49” kilka reporterskich wzmianek, dotyczących głównie organizowanych w Londynie wystaw $^{53}$.

Zachowane w Pracowni-Archiwum Oficyny Poetów i Malarzy listy Ryszarda Piestrzyńskiego ${ }^{54}$ do K. i C. Bednarczyków z lat 1950-1951 świadczą o udanej współpracy redaktora z przyszłymi wydawcami. R. Piestrzyński nie tylko potrafił docenić poezję C. Bednarczyka, lecz także dołożył starań, aby Fundusz Wydawniczy „Oficyny Poetów i Malarzy” zyskał na łamach „Orła Białego” pewien rozgłos. Nalegał również, by kompozycję oficynowych kolumn omawiać osobiście, nie listownie. C. Bednarczyk też wielokrotnie miał okazję towarzyszyć R. Piestrzyńskiemu w pracach nad stroną Oficyny w tłoczni, odkrywając przy tym arkana warsztatu drukarskiego. Wspólne planowanie kolumny oraz wizyty w tłoczni (m.in. udział w łamaniu tygodnika) stanowiły zapewne bezcenną okazję do nauki dla debiutującego wydawcy i drukarza.

W zespole tym czasem dochodziło jednak do nieporozumień. Redaktor bowiem nie zawsze zgadzał się z dokonanym przez C. Bednarczyka wyborem wierszy, nad który przedkładał niekiedy własne propozycje. W liście z 23 maja 1951 r. tak wyraził swoje niezadowolenie:

Jak już Pan widział w „Orle”, kolumna poszła zgodnie z Pana życzeniami. Co prawda uważam, że tym razem dobór wierszy był nieco słabszy. No ale trudno, by zawsze były to utwory pierwszorzędne ${ }^{55}$.

Z kolei w sierpniu tegoż roku R. Piestrzyński odmówił londyńskiemu wydawcy publikacji rzekomo kontrowersyjnego szkicu Walka o ksiażkę $i$ wydawnictwo ${ }^{56}$ oraz przestrzegł przed rozpowszechnianiem go. Artykuł stanowił

53 Zob. np. A. Drwęska, Wystawa „Grupy 49”, „Orzeł Biały”, 28.01.1950, nr 4, s. 3; taż, Polskie wystawy w Londynie ,, Grupy 49”, „Orzeł Biały”, 19.08.1950, nr 32-33, s. 6.

54 R. Piestrzyński (1902-1962) - dziennikarz, pisarz, wiceprezes Związku Dziennikarzy Rzeczypospolitej Polskiej. Przed wojną związany ze środowiskiem Stronnictwa NarodowoDemokratycznego. Od 1942 r. członek redakcji „Orła Białego”, a w latach 1945-1957 r. - jego redaktor naczelny. Od 1945 r. stale pisywał również do „Dziennika Polskiego i „Dziennika Żołnierza” w Londynie. W serii „Biblioteka Orła Białego” wydał zbiór artykułów z czasu wojny W pót drogi (Londyn 1946).

55 PA OPiM, sygn. akc. 745, List R. Piestrzyńskiego do C. Bednarczyka z 23 maja 1951 r., k. 8.

56 Maszynopis zachował się w materiałach redakcyjnych C. Bednarczyka (PA OPiM, sygn. 3054). Widnieje na nim ręcznie dopisana data: „listopad 49”. Jest to zastanawiające, ponieważ autor wspomniał w artykule o już wydanym (wiosną 1950 r.) tomie Chwila nocna J. Olechowskiego i zapowiedział następną publikację, Pola minowe M. Czuchnowskiego, które miały się ukazać w lutym $1951 \mathrm{r}$. 
sprawozdanie z krótkiej działalności Oficyny Poetów i Malarzy, w którym autor najpierw wyraził swoją wdzięczność wobec życzliwych jej redakcji „Dziennika Polskiego”, „Orła Białego”, „Kultury” i „Wiadomości”, następnie zaś zarzucił nieprzychylność Katolickiemu Ośrodkowi Wydawniczemu „Veritas" ${ }^{57}$. Główne oskarżenie dotyczyło „zorganizowanego przemilczenia” oraz obojętności środowiska „Veritasu” wobec prób ocalenia polskiej książki na emigracji, które - poprzez ufundowanie własnego wydawnictwa - pragnął wesprzeć C. Bednarczyk. R. Piestrzyński mógł obawiać się reakcji czytelników m.in. na następujące, szorstkie słowa: „Zorganizowane przemilczenie jest równoznaczne ze złośliwą intencją utrącenia naszej skromnej inicjatywy"58. Ponadto autor nie szczędził gorzkich słów krytyki Związkowi Pisarzy Polskich na Obczyźnie, do którego miał żal za brak inicjatywy i bierność. $Z$ drugiej strony jednak C. Bednarczyk zdobył się na serdeczność nie tylko względem subskrybentów Oficyny, lecz także Antoniego Bogusławskiego, T. Terleckiego i Wacława Grubińskiego.

Nie było to jedyne napomnienie ze strony bardziej doświadczonego redaktora. W odpowiedzi na list C. Bednarczyka z 22 listopada 1950 r. i załączony do niego artykuł R. Piestrzyński namawiał autora do złagodzenia tonu wypowiedzi:

Pana artykuł o wieczorze autorskim jest świetny, cięty i trafny, ale obawiam się, że będzie wymagał przede wszystkim odrobinę litości dla Naglerowej i wypowiedzenia się w nieco łagodniejszej formie o Balińskim. [...] Przyszło mi na myśl, czy by w ogóle nie wprowadzić takiej ciętej i podniecającej rubryki: „Wydaje mi się, że”. Wówczas byłaby to rubryka Pana niejako, w której mógłby Pan bardziej swobodnie wypowiadać swe poglądy niezależnie od redakcji i wszystkich świętych ${ }^{59}$.

W numerze „Orła Białego” z 16 grudnia 1950 r. C. Bednarczyk po raz pierwszy (i jedyny) publikuje w autorskiej rubryce „Wydaje mi się, że...” poprawiony zgodnie z sugestią redaktora naczelnego artykuł. Szkic recenzyjny zawierał przemyślenia dotyczące pisarzy występujących podczas londyńskich wieczorów autorskich. Cierpkich komentarzy autor nie szczędził

57 C. Bednarczyk narzekał na „Veritas” również w listach do redaktora „Kultury”: „Przyjaciół nam przybywa. Nawet Bielatowicz uśmiecha się w naszą stronę. Veritas zły, że mu wyrosło pod bokiem wydawnictwo drukujące książki bez błędów". AIL, sygn. KOR RED Bednarczyk, List C. Bednarczyka do J. Giedroycia z 9 maja 1950 r. Powodem tej uszczypliwości mógł być też sprzeciw „Veritasu” wobec wydrukowania przez K. i C. Bednarczyków pierwszej książki Oficyny, tj. Chwili nocnej J. Olechowskiego, zawierającej akty Z. Turkiewicza. Zob. maszynopis artykułu Bednarczyka Oficyna Poetów i Malarzy w: PA OPiM, sygn. 3054.

58 Maszynopis artykułu C. Bednarczyka Walka o książke i wydawnictwo w: PA OPiM, sygn. 3054.

59 PA OPiM, sygn. akc. 745, List R. Piestrzyńskiego do C. Bednarczyka z 22 listopada 1950 r., k. 4. 
Tadeuszowi Nowakowskiemu, Jerzemu Stempowskiemu i K. Sowińskiemu. Łaskawiej obszedł się natomiast z M. Czuchnowskim i T. Sułkowskim.

Redakcja tygodnika wspierała K. i C. Bednarczyków również w ich przedsięwzięciu wydawniczym, przypominając od czasu do czasu swoim czytelnikom o cennej inicjatywie poetów i malarzy. Dobrym przykładem tej dbałości były wzmianki w regularnie ukazującej się kronikarskiej rubryce „Życie kulturalne w kraju i na obczyźnie". Jedna z wiadomości dotyczyła przyjęcia delegacji Oficyny Poetów i Malarzy przez generała Władysława Andersa 24 lipca 1950 r. i wręczenia mu pierwszego tomu artystycznego wydawnictwa. Autor tej krótkiej notatki anonsował: „Gen. Anders wyraził uznanie dla inicjatywy kulturalnej «Oficyny» i gratulował pięknie wydanego tomiku" ${ }^{60}$. Za inną formę wyrażanego poparcia trzeba uznać zgodę redakcji na publikację rejestru ofiarodawców, którzy wpłacili pieniądze na Fundusz Wydawniczy „Oficyny Poetów i Malarzy”61.

Z kolei w „Orle Białym” z 29 lipca 1950 r. pojawiła się obszerna recenzja Chwili nocnej J. Olechowskiego pióra T. Nowakowskiego pt. Poeci zaczynają się ruszać z podtytułem Pierwszy tomik ,Oficyny Poetów i Malarzy”62. Tuż obok redakcja zamieściła komunikat o subskrypcji na Fundusz Wydawniczy „Oficyny Poetów i Malarzy” ${ }^{\text {"3 }}$. W tym samym numerze pisma opublikowano wiersz C. Bednarczyka (Pragnienia), a w bezpośrednim sąsiedztwie liryku - rysunek Z. Turkiewicza (Notatka z Londynu). Kompozycję można chyba uznać za zapowiedź poetycko-literackich arkuszy przygotowywanych przez założycieli Oficyny i drukowanych gościnnie w tygodniku od sierpnia 1950 do listopada $1951 \mathrm{r}$.

60 „Orzeł Biały”, 26.08.1950, nr 34, s. 3.

61 Np. „Orzeł Biały”, 2.12.1950, nr 48, s. 3: „Na Fundusz Wydawniczy «Oficyny Poetów i Malarzy» wpłaciły następujące osoby:

1. p. E. Rudnicki (Edinburgh) - 13 sh.

2. p. Franciszek Gonczyński (Australia) - £ A. 2.10 sh.

3. p. Tadeusz Szczepańczyk (U.S.A.) - 50 cent

4. p. Aleksander Janta (U.S.A.) - \$1.50 cent.

5. p. Zofia Snawadzka (Londyn) -5 sh.

6. p. Ksawery Ciechanowski (Belgia) - 50 frb.

7. Bezimiennie (Argentyna) - 30 pesos.

8. p. F.J. Walus (U.S.A.) - \$2”.

62 T. Nowakowski, Poeci zaczynaja się ruszać, „Orzeł Biały”, 29.07.1950, nr 30, s. 3. Publicysta o inicjatywie K. i C. Bednarczyków napisał z przymrużeniem oka: „Niedawno temu powstała w Londynie «Oficyna Poetów i Malarzy», coś na kształt konfraterni - spółdzielni kasy samopomocowej, loży masońskiej czy innego artystycznego ku-klux-klanu". Nie można jednak powiedzieć, że stosunek T. Nowakowskiego do przedsięwzięcia był prześmiewczy. Wręcz przeciwnie - po pierwsze napisał rzeczowe i staranne omówienie tomu Olechowskiego, po drugie zaś w zakończeniu artkułu wyraził wielką nadzieję na powodzenie cennej inicjatywy.

63 Treść subskrypcji w ,Orle Białym” brzmiała niemal identycznie jak jej wersja wydrukowana w lipcowym numerze „Kultury” z tego samego roku. Nie pojawiło się w niej sformułowanie dotyczące przywilejów subskrybentów i osób wpłacających na Fundusz Wydawniczy. Dało się też dostrzec różnicę w końcowych wskazówkach objaśniających tryb zgłaszania prenumerat i datków. 
Redagowana przez K. i C. Bednarczyków kolumna zatytułowana Oficyna Poetów i Malarzy ukazała się po raz pierwszy w „Orle Białym” 5 sierpnia 1950 r. ${ }^{64}$ Nie była sygnowana znakiem wydawniczym K. i C. Bednarczyków mimo tego, że został on po raz pierwszy użyty na stronie tytułowej wydanego już w kwietniu 1950 r. tomu J. Olechowskiego ${ }^{65}$. Nota wprowadzająca, podpisana przez Oficynę Poetów i Malarzy, przyjęła brzmienie:

Dzięki uprzejmości redakcji ORŁA BIAŁEGO, dla pogłębienia zainteresowań twórczością poetów i malarzy na emigracji, od niniejszego numeru poczynając, zamieszczać będziemy w pewnych odstępach czasu utwory członków i tych KOLEGów, którzy wyrażą chęć znalezienia się w ramach OFICYNY ${ }^{66}$.

Aranżacja poetycko-graficzna zajęła trzy gazetowe łamy i jeśli wziąć pod uwagę format periodyku, mogła robić na czytelnikach duże wrażenie. W liście z 28 sierpnia 1950 r. R. Piestrzyński pochwalił redaktorskie przedsięwzięcie K. i C. Bednarczyków: „Pańska strona istotnie bardzo ładnie wypadła i ogólnie się podobała”. Swoje wiersze w inauguracyjnej edycji arkusza ogłosili Jerzy Niemojowski (Nie czas), Mieczysław Lurczyński (Hoplita), M. Czuchnowski (Przedwiośnie w górach) oraz C. Bednarczyk (Błogosławiona praca). Utworom towarzyszyły rysunki M. Kościałkowskiego (Fantazja) oraz Edwarda Matuszczaka (Zdziwienia).

Drugi arkusz pojawił się w numerze periodyku z 23 września $1950 \mathrm{r}^{67}$ Zawierał wiersze C. Bednarczyka z cyklu Pejzaże (Patrze - dedykowany żonie, Krystynie, Okno), M. Czuchnowskiego (Mgła poranna) oraz dwie ilustracje Z. Turkiewicza (reprodukcja obrazu Madonna, rysunek Notatka z Londynu).

Do publikacji trzeciej kolumny Oficyny Poetów i Malarzy doszło 18 listopada $1950 \mathrm{r}^{68}$ Tym razem zarezerwowano dla niej całą trzecią stronę tygodnika, na której znalazły się utwory J. Radzymińskiej (Ciężki pierścień), J. Żywiny (Obłoki), C. Bednarczyka (Dzieciństwo), M. Łysakowskiego (Stowo do przyjaciela w Kraju), M. Czuchnowskiego (Woty). Akcent graficzny stanowiły dwa rysunki E. Matuszczaka (Pałac pięknej branki oraz Ludzie i zwierzęta). Na stronie widniała również nota sporządzona przez redakcję „Orła Białego”:

64 Należy dodać, że za opublikowane w „Orle Białym” wiersze oraz reprodukcje dzieł graficznych i malarskich autorzy otrzymywali honorarium (odpowiedzialnym za rozliczenia był Paweł Zaremba).

65 Znak wydawniczy K. i C. Bednarczyków nie został opublikowany w żadnym z dziesięciu arkuszy „Oficyny Poetów i Malarzy” wydrukowanych w „Orle Białym”.

66 „Orzeł Biały”, 5.08.1950, nr 31, s. 3.

67 Zob. „Orzeł Biały, 23.09.1950, nr 38, s. 3.

68 Zob. „Orzeł Biały”, 18.11.1950, nr 46, s. 3. 
Drukujemy dziś trzeci z kolei arkusz „Oficyny Poetów i Malarzy”, zwracając jednocześnie uwagę naszym czytelnikom na wysiłek artystyczny i wydawniczy tego zespołu, który może poszczycić się już pięknymi wynikami pracy, wszczętej z samodzielnej i zasługującej na poparcie ze strony społeczeństwa inicjatywy ${ }^{69}$.

Czwarty arkusz, specjalny, zatytułowany Oficyna Poetów i Malarzy. Boże Narodzenie 1950 zdobił świąteczne, dwutygodniowe wydanie periodyku z 23 grudnia 1950 r. $^{70}$ Składały się nań wiersze J. Żywiny (O wiosce co już nie żyje), C. Bednarczyka (Z pamiętnika, Plaża), J. Radzymińskiej (Przyjaźń), M. Czuchnowskiego (Łąka) oraz rysunek M. Lurczyńskiego (Ulica paryska) i fotografia rzeźby Tadeusza Kopera (Głowa).

Zawartość następnych pięciu arkuszy ujmuje poniższe zestawienie:

- Piąty arkusz Oficyna Poetów i Malarzy z 10 lutego 1951 r. $^{71}$ :

wiersze C. Bednarczyka (Śnieg), J. Żywiny (Odwiedziny), J. Radzymińskiej (Białe sidła), Stefana Legeżyńskiego (U studni), Seweryna K. Ehrlicha (Italia bella). Rysunek M. Kościałkowskiego (Żniwa) oraz reprodukcja obrazu Z. Turkiewicza (Św. Franciszek $i$ św. Klara).

- Szósty arkusz Oficyna Poetów i Malarzy. Wielkanoc 1951 z 24 marca 1951 r. ${ }^{72}$ : wiersze J. Żywiny (Żona), J. Niemojowskiego (Powrót w Litwę), B. Kobrzyńskiego (Odyseusz), M. Lurczyńskiego (Nad kanałem Am Fleet) i M. Łysakowskiego (Słowo). Rysunki A. Drwęskiej (Dziecko, Łabędzie) oraz reprodukcja obrazu Z. Turkiewicza (Koncert).

- Siódmy arkusz Oficyna Poetów i Malarzy z 19 maja 1951 r. $^{73}$ :

wiersze S. Legeżyńskiego (Delfin), J. Radzymińskiej (Pytanie wieczorne), C. Bednarczyka (Drzwi), J. Żywiny (Trafalgar Square), Józefa Bujnowskiego (Z nastrojów). Dwie ilustracje Krystyny Herling (Koncert, Cyrk).

- Ósmy arkusz Oficyna Poetów i Malarzy z 4 sierpnia 1951 r. ${ }^{74}$ : wiersze C. Bednarczyka (*** [Spójrz wokół drzewa...], Mabledon Park), Alfreda J. Wiznera (Miłość), H. Mirzwińskiego (Żebrak), J. Żywiny (Zły sen), J. Bujnowskiego (Rzecz o przemijaniu). Ilustracje Z. Turkiewicza (Kwiaty) oraz M. Kościałkowskiego (Rysunek).

- Dziewiąty arkusz Oficyna Poetów i Malarzy z 6 października 1951 r. ${ }^{75}$ : wiersze C. Bednarczyka (Przemiany, Wiersz nie poetycki), M. Lurczyńskiego (Motyl), A.J. Wiznera (*** [Włosy drzew na niebie żółtym...]),

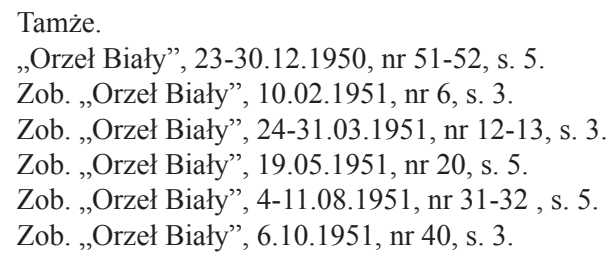


J. Radzymińskiej (Strofa po burzy). Rysunki M. Lurczyńskiego (Cannes, stara kaplica) oraz M. Kościałkowskiego (Szkic).

Ostatni arkusz został dołączony do „Orła Białego” 17 listopada $1951 \mathrm{r}$. Swoje wiersze ogłosili w nim C. Bednarczyk (Rumiany dzień z dedykacją dla Krystyny Herling-Grudzińskiej, Uchylam kapelusza), J. Radzymińska (Żagiew z dedykacją dla C. Bednarczyka), H. Mirzwiński (Wiatr) oraz M. Lurczyński (Cyrk). Jeśli chodzi o grafiki, zamieszczono prace Z. Turkiewicza ( $W$ porcie) oraz M. Lurczyńskiego (Cannes Suquet). Egzemplarze „Orła Białego”, w których - w ramach przerwy - nie drukowano arkuszy Oficyny, nie były jednak pozbawione akcentu poetyckiego i artystycznego. W międzyczasie tłoczono w nich wiersze m.in. C. Bednarczyka, M. Czuchnowskiego, J. Niemojowskiego, J. Radzymińskiej oraz reprodukcje Z. Turkiewicza i E. Matuszczaka.

Zamysł tworzenia aranżacji poetycko-artystycznych przetrwał jednak i powrócił ponownie po kilkunastu latach z jeszcze większym rozmachem na łamach redagowanego przez K. i C. Bednarczyków kwartalnika „Oficyna Poetów". Do szóstego zeszytu periodyku z sierpnia 1967 r. dołączono bowiem pierwszy numer Arkuszy poetów i malarzy, na który złożyły się wiersze K. Bednarczykowej (Lzy, Czytajac Miłosza, Umowa, Przechadzka z psem i Wyzwania) oraz grafiki F. Topolskiego w kolorze, wyobrażające posągową i strzelistą K. Bednarczykową jako drzewo z konarami.

W numerze „Orła Białego” z sierpnia 1952 r. na miejscu oficynowego arkusza pojawił się nowy, opatrzony nagłówkiem Poezja i Grafika ${ }^{76}$. Podobieństwo między dwiema kolumnami dało się zauważyć nie tylko w ich nazwach, lecz także w redaktorskim zamyśle. Wierszom i grafikom towarzyszył zwięzły komunikat wyjaśniający zmianę:

Poświęcając stronę „Poezji i Grafice”, „Orzeł Biały” pragnie nadal być żywym łącznikiem między wolną twórczością poetycką i plastyczną a jak najszerszym kręgiem czytelników. Prowadzenie tej strony, która ukazywać się będzie w odstępach dwumiesięcznych, objął red. J. Ostrowski ${ }^{77}$.

Część poetycka tego działu obejmowała wiersze M. Łysakowskiego (Impromptu, Stowo do przyjaciela), K. Sowińskiego (Połowa), J. Niemojowskiego (Rysunek sztyletem) oraz J. Żywiny (Ucieczka). W części plastycznej swoje grafiki opublikowali Tadeusz Beutlich (Scena) oraz Leon Piesowocki (Stary wiadukt). Następne edycje arkusza Poezja i Grafika, ogłaszane w 1952 i 1953 r. ${ }^{78}$, umożliwiły czytelnikom „Orła Białego” obcowanie m.in.

\footnotetext{
76 Zob. „Orzeł Biały”, 2-9.08.1952, nr 31-32, s. 5.

77 Jak wyżej.

78 Zob. „Orzeł Biały”, 25.10.1952, nr 43, s. 3; 22-27.12.1952, nr 51/52, s. 3; 14.02.1953, nr 7, s. 3.
} 
z twórczością poetycką i plastyczną H. Mirzwińskiego, B. Przyłuskiego, W. Iwaniuka, E. Pounda (w przekładzie J. Niemojowskiego), T. Beutlicha, Stefana Starzyńskiego, Aleksandra Wernera, Kazimierza Dźwiga oraz Z. Turkiewicza.

C. Bednarczyk tak oto opisał swoje relacje z zespołem „Orła Białego”:

Okres ten wspominamy jako jeden z najprzyjemniejszych z dość licznych kontaktów z ludźmi i instytucjami emigracyjnymi. Podobnie życzliwie układała się współpraca z redaktorem Pawłem Zarembą po odejściu red. Piestrzyńskiego ${ }^{79}$.

„Kultura” oraz „Orzeł Biały” nie były jedynymi periodykami, które użyczyły swoich łamów założycielom Oficyny Poetów i Malarzy. K. i C. Bednarczykowie mogli liczyć również na przychylność redaktorów „Polski Walczącej”, „Ostatnich Wiadomości”, argentyńskiego „Głosu Polskiego”, sztokholmskich „Wiadomości Polskich” oraz londyńskich „Wiadomości”. Współpraca z J. Giedroyciem i R. Piestrzyńskim stanowiła jednak dla debiutujących wydawców poezji o tyle cenniejsze doświadczenie, że zostali przyjęci w poczet redaktorów obu pism, choć nie zawsze mieli szansę dowieść swojej samodzielności. Odpowiadali przez pewien czas za dział poetycki tak „Kultury”, jak i „Orła Białego”, do których proponowali autorskie zestawienia poezji i grafiki. Koncepcja ta, według której pisarza i artystę należy uznać za równoprawnych autorów dzieła, znalazła też wyraz w pierwszych publikacjach oznaczonych sygnetem wydawniczym Oficyny Poetów i Malarzy - jednym z przejawów autonomii pisarza i grafika były dwie równoważne karty tytułowe. Zgodnie z tą ideą K. i C. Bednarczykowie redagowali od 1966 r. swój kwartalnik „Oficyna Poetów”. Mimo tego, że krótko pełnili oni funkcję współredaktorów działów artystycznych wspomnianych czasopism, a nadzieje pokładane we wzajemnych kontaktach nie zostały w pełni zrealizowane, współpraca ta była ważnym epizodem w dziejach zarówno Oficyny Poetów i Malarzy, jak i zespołów „Kultury” i „Orła Białego”. Przypomnienie o tych przedsięwzięciach dopełnia znany nam obraz życia literackiego powrześniowej emigracji. Warto byłoby też - na próbę - wyobrazić sobie, jakie miejsce w „Kulturze” zajmowałyby poezja i grafika, gdyby losy współpracy potoczyłyby się inaczej. Gdyby „Kultura” była gmachem, a przy niej stała Oficyna Poetów i Malarzy.

79 C. Bednarczyk, W podmostowej arkadzie. Wspomnienia drukarza i wydawcy londyńskiej oficyny, Londyn 1988, s. 98. 


\section{Streszczenie}

W oparciu przede wszystkim o źródła archiwalne podjęłam w artykule próbę zwięzłego omówienia udziału Krystyny i Czesława Bednarczyków, założycieli emigracyjnej Oficyny Poetów i Malarzy, w pracach redakcyjnych zespołu paryskiej „Kultury” i londyńskiego „Orła Białego”. Zarówno szczegóły tej współpracy, jak i redaktorskie dokonania debiutujących wydawców poezji nie wzbudziły dotychczas żywszego zainteresowania badaczy życia literackiego emigracji. Tymczasem na początku lat pięćdziesiątych Bednarczykowie zasadniczo wpływali na podniesienie poziomu poetyckiego i artystycznego obu periodyków, publikując gościnnie autorskie całostronicowe kompozycje wierszy i grafik malarzy oraz poetów, których poznali w większości na wojennym szlaku II Korpusu. W „Kulturze” ukazały się one tylko dwa razy (w kwietniu i listopadzie 1950 r.), na łamach „Orła Białego” zaś dziesięć razy (w latach 1950-1951). Uczestnictwo w tworzeniu numerów miesięcznika oraz tygodnika stanowiło dla Bednarczyków szansę nie tylko na redaktorski debiut i edytorską wprawkę, lecz także na reklamę własnego wydawniczego przedsięwzięcia. Zarówno bowiem Jerzy Giedroyc, jak i Ryszard Piestrzyński wspomogli nowo założoną Oficynę Poetów i Malarzy, zamieszczając w kierowanych przez siebie pismach apele, ogłoszenia i artykuły promujące tę inicjatywę. Zatem mimo że opisana współpraca stanowiła dla Bednarczyków dodatkowe i krótkotrwałe zatrudnienie, należy uznać możliwość równoczesnego redagowania działu poetyckiego „Kultury” oraz „Orła Białego” za niemałe ich osiągnięcie i przywrócić temu epizodowi należne mu $\mathrm{z}$ tej racji miejsce $\mathrm{w}$ literaturze przedmiotu.

Słowa kluczowe: Oficyna Poetów i Malarzy - „Kultura” - „Orzeł Biały” polska prasa na uchodźstwie - polska poezja emigracyjna.

\section{Summary}

\section{Krystyna and Czesław Bednarczyk's contribution to edition of „Kultura” and „Orzeł Biały” on the turn of the 40 s of $20^{\text {th }}$ Century.}

The article presents a little-known episode from the history of Polish press in exile. Its subject is Krystyna and Czesław Bednarczyk's editorial cooperation with „Kultura” („Culture”, the most prominent émigré literary magazine of that time) and „Orzeł Biały” (,The White Eagle”, the Polish $2^{\text {nd }}$ Corps' weekly magazine) in the 1950s. 
The article examines and briefly describes the archival sources on this topic. They were collected mostly in the research centres for culture of Polish emigration in Maisons-Laffitte (Literary Institute), Torun (Archives of Polish Emigration) and Cracow (the manuscript collection inherited by the Jagiellonian University through the last will of Krystyna Bednarczyk) and present the Bednarczyk's contribution to artistic development of both magazines.

Czesław and Krystyna Bednarczyk were founders of the publishing house and printing company Oficyna Poetów i Malarzy (Poets and Painters' Press). Analysis of their correspondence, especially with Jerzy Giedroyc and Ryszard Piestrzyński, proves that the cooperation with editorial staffs used to be mutually beneficial, as „Kultura” and „Orzeł Biały” helped Bednarczyks to promote their own undertaking. Although short, this episode in their biography therefore deserves to be considered as an achievement worth being remembered.

Key words: Oficyna Poetów i Malarzy - „Kultura” - „Orzeł Biały” - Polish press in exile - Polish émigré poetry. 